\title{
Sights and Sounds of Death Valley: A Close Reading of Ezekiel 37:1-14
}

\author{
Amelia Rebecca BaSdeo-Hill (University OF South Africa)
}

\begin{abstract}
Owing to the visual and auditory elements found in Ezekiel's vision of the valley of dry bones, this article employs the themes of seeing and hearing as a fitting biblical approach to Ezekiel 37:1-14. A meticulous study of the text demonstrates that Ezekiel intentionally used visual and auditory language to organize the literary structure of the vision, to invite the reader to see, hear, and experience the event along with him, and to intimately encounter the presence of $Y H W H$.
\end{abstract}

KEYWORDS: seeing, hearing, dry bones, hope, restoration, Ezekiel

\section{A INTRODUCTION}

The prophet Ezekiel faced the difficult and unenviable task of prophesying to the "rebellious nation" of Israel (Ezek 2:3). Israel's recalcitrant behaviour was not merely an evanescent phase in their history, but rather, their deliberate and conscious rebellion against YHWH was intergenerational (Ezek 2:3-4; 3:7), rendering a callous defiance to the voice of YHWH. Inevitably, resolute stubbornness had become an inherent trait of Israel's character. Yet, in spite of Israel's irremediable rebellion and rejection of YHWH's message, Ezekiel must still speak YHWH's word (Ezek 2:7). That is, Ezekiel must speak to an audience who had diminished, domesticated, dismissed, and disregarded the word of YHWH. The prophet, therefore, must dare to assault the imagination, ${ }^{1}$ 'offend the reason', ${ }^{2}$ and unsettle the 'settled reality' ${ }^{3}$ of his hearers. Indeed, he must deliberately use imagery and language that are visually and audibly evocative, riveting, sensational, and dramatic. It is no wonder that the visions, imagery, and metaphors of the book of Ezekiel stand out among the prophetic literature as sublime, bizarre, disturbing, and dreadful.

\footnotetext{
* Submitted: 15/08/2018; peer-reviewed: 08/10/2018; accepted: 09/01/2019. Amelia Rebecca Basdeo-Hill, "Sights and Sounds of Death Valley: A Close Reading of Ezekiel 37.1-14,” Old Testament Essays 31 no. 3 (2018): 534-552. DOI: https://doi.org/10.17 159/2312-3621/2018/v31n3a8.

Walter Brueggemann, Finally Comes the Poet: Daring Speech for Proclamation (Minneapolis: Fortress Press, 1989), 3.

2 Garrett Green, "'The Bible As ...': Fictional Narrative and Scriptural Truth," in Scriptural Authority and Narrative Interpretation (ed. Garrett Green; Philadelphia: Fortress Press 1987), 94.

3 Brueggemann, Finally Comes the Poet, 4.
} 
Considering the book's elaborate visual and auditory imagery, Ezekiel invites us to see and hear the text. However, modern scholarship has focused more on the written language of the text and has not fully appreciated the visual and auditory elements of the visions of Ezekiel. Therefore, the poor attention given to the close relationship between seeing and hearing in Ezekiel justifies the significant need for this article. Since the themes of seeing and hearing play a central role in the book of Ezekiel, ${ }^{4}$ it is a suitable approach to the book of Ezekiel. By using a literary-theological and exegetical approach, this study seeks to demonstrate that the interface between seeing and hearing in Ezekiel 37:1-14 yields a fresh encounter with YHWH and YHWH's word. Moreover, a close examination of Ezekiel 37:1-14 reveals that the prophet diligently employs visual and auditory images and terminology to convey YHWH's message of hope to the disconsolate exilic community.

\section{B SEEING AND HEARING: A BIBLICAL APPROACH TO EZEKIEL 37:1-14}

The book of Ezekiel is a sensory text, loaded with fantastic and bold imagery that appeals to all five senses. From the outset, things are seen, heard, smelled, tasted, and touched. ${ }^{5}$ Although the book engages all the senses, the close relationship between seeing and hearing is axiomatic in Ezekiel. The book of Ezekiel opens with a striking and captivating sight of YHWH's glory. The heavens open and Ezekiel sees "visions of God" (1:1). He limns his visionary experience with bold, bright, and vibrant colours to grab the attention of his hearers. He creates a sequence of images of what he sees and hears by using the

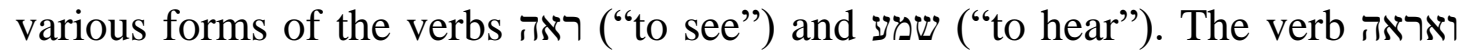
("and I saw") occurs three times in 1:4, 1:15, and 1:27 [ואשמע ("and I heard") appears once in verse 24, and ראיתי ("I saw") occurs in verse 27. The visionary experience ends in verse 28 with ואראה ("and I "and ("and I saw it") and heard"). ${ }^{6}$ Furthermore, Ezekiel uses the related noun harm ("vision") fifteen times in the first chapter to signal what he sees, and as he narrates what he sees,

$4 \quad$ In my doctoral thesis, "The Relationship between the Glory of Yahweh and the Holiness of Yahweh: A Literary-Theological Study from a Pentecostal Context", PhD thesis, University of South Africa, 2018, I propose that the themes of seeing and hearing serve as an appropriate biblical approach to the book of Ezekiel.

5 John Christopher Thomas, The Apocalypse: A Literary and Theological Commentary (Cleveland, TN: CPT Press, 2012), 1, states that "The book of Revelation is the most sensual document in the NT, filled with references to things seen, heard, smelled, touched, and tasted!" Thomas' assertion of Revelation may certainly apply to the book of Ezekiel, and thus, rendering the book of Ezekiel 'the most sensual' text in the OT.

6 Ellen Van Wolde, "The God Ezekiel 1 Envisions," in The God Ezekiel Creates (eds. Paul M. Joyce and Dalit Rom-Shiloni; London: Bloomsbury T\&T Clark, 2015), 88. 
קול ("sound/voice") seven times to describe what he hears. Clearly, seeing and hearing are the means by which Ezekiel senses, receives, and encounters the word of YHWH. ${ }^{8}$ Chapter one, therefore, launches the tight relationship between seeing and hearing in the book of Ezekiel.

Visual and aural languages are not confined to Ezekiel's first chapter only, but rather visual and auditory expressions permeate the entire word of YHWH that occurs to the prophet. Certainly, the themes of seeing and hearing function as the fulcrum of YHWH's word in Ezekiel. As previously mentioned, the book of Ezekiel characterizes Israel's sin as rebellion against YHWH, and this rebellion is directly related to seeing and hearing: "Son of man, you are living in the midst of a rebellious house. They have eyes to see, but do not see, ears to hear, but do not hear because they are a rebellious house" (12:2). Clearly, rebellion against YHWH is a failure to see and hear YHWH.

This immediate connection between rebellion and the themes of seeing and hearing materializes throughout the book. After seeing and hearing the glory of YHWH (chapters one and two), Ezekiel feels a bitter and age in his spirit (3:14), and sits in silence, resisting his call for an entire week (3:15). Following the week of silence, Ezekiel is given a grave warning about disregarding his prophetic call $(3: 16-21) .{ }^{9}$ These events suggest that if Ezekiel does not obey what he sees and hears, then he will also be guilty of rebellion against YHWH.

Whereas the book's opening vision demonstrates an implied relationship between rebellion and the themes of seeing and hearing, the last vision of the book concretely links rebellion to the lack of seeing and hearing YHWH. Keeping in mind that a failure to see and hear YHWH results in rebellion against YHWH, it should not be taken for granted that the first words spoken to Ezekiel in the final vision of the return of YHWH's glory include the commands to "see ... and hear ..." (40:4). Thus, the commands not only underscore seeing and hearing as an appropriate approach to the book of Ezekiel, but the commands also convey the theological significance of seeing and hearing the word of YHWH. It is necessary for Ezekiel to see, hear, and pay close attention because he must tell the people of Israel everything he sees and hears in this vision (40:4). The sole purpose for relaying all that he sees and hears is made explicit in 43:10: "so that they may be ashamed of their sins." By describing the new temple to the house of Israel, YHWH forces Israel to recognize and take responsibility for the magnitude of their idolatry and their various violations of YHWH's glory and

7 Van Wold, "The God Ezekiel 1 Envisions," 89.

8 Cf. Willie Wessels, "Prophetic Sensing of Yahweh's Word," HTS Teologiese Studies/Theological Studies 71(3), 1. http://dx.doi.org/10.4102.hts.v71i3.2923.

9 Iain M. Duguid, Ezekiel (Grand Rapids: Zondervan, 1999), 313; Daniel I. Block, The Book of Ezekiel: Chapters 1-24 (Grand Rapids: Eerdmans, 1997), 120. 
holiness. ${ }^{10}$ The awareness of their sins will produce guilt and shame that express genuine repentance and effect transformation. ${ }^{11}$ Again, in Ezekiel 44:5, YHWH commands Ezekiel to "pay attention, see with your eyes, and with your ears hear everything I tell you concerning all the statutes of the temple of YHWH and all its laws." The repeated commands, "see ... hear ... pay attention" indicate that these are not random commands, but words carefully chosen by YHWH to remind Ezekiel and his hearers that YHWH's laws and instructions must be seen and heard! The book of Ezekiel conclusively establishes that to see with the eyes is to hear and obey the words of YHWH, and a refusal to see and hear the word of YHWH is to revolt against him.

Accordingly, seeing and hearing are not passive sensory experiences of YHWH, but rather, seeing and hearing demand an active response to YHWH, an

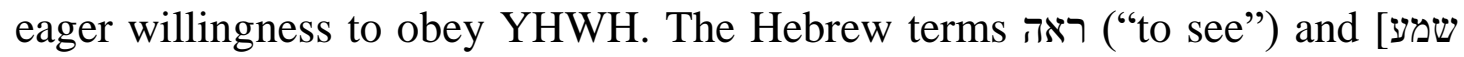
("to hear") often appear together in the OT to describe a singular perception (Deut 29:3; Isa 6:9ff; Jer 5:21; Prov 20:12; Eccl 1:8). In these OT texts, seeing and hearing do not exist independently of each other, but rather each sense interrelate to develop and enlighten the other. ${ }^{12}$ The idea conveyed is that without the act of ראה that which is heard is merely empty form of erudition. That is, the act of ראה creates a dynamic, enriching, and complete experience for the hearer. ${ }^{13}$

Thus, Scripture frequently demonstrates that seeing and hearing YHWH is to encounter YHWH. According to Abraham Even-Shoshan, all of the verb forms of the Hebrew word ראה ("to see") are found 1303 times in the OT (14 $^{14}$ and 73 times in the book of Ezekiel. ${ }^{15}$ The basic meaning of the verb is "to see," "look at," and "inspect with the eyes;" ("to see") widens beyond the physical visual act of seeing to include meanings such as "to discern," "to discover," "to encounter," "to know," "to perceive," "to

10 Daniel Block, The Book of Ezekiel: Chapters 25-48 (Grand Rapids: Eerdmans, 1998), 589; Christopher J. H. Wright, The Message of Ezekiel: A New Heart and a New Spirit (Leicester: Inter-Varsity, 2001), 337.

11 Cf. Walther Zimmerli, Ezekiel: A Commentary on the Book of the Prophet Ezekiel Chapters 25-48 (trans. James D. Martin; Philadelphia: Fortress Press, 1983), 2:418-19.

12 Sheri L. Klouda, "The Dialectical Interplay of Seeing and Hearing in Psalm 19 and Its Connection to Wisdom," Bulletin for Biblical Research 10 (2000/2): 182.

13 Hans F. Fuhs, "ראה", TDOT 9:216.

14 Fuhs, TDOT 9:212.

15 Abraham Even-Shoshan, A New Concordance of the Old Testament: Using the Hebrew and Aramaic Text (2 ${ }^{\text {nd }}$ ed.; Jerusalem: "Kiryat-Sefer", 1989), 1041-45.

16 Robert D. Culver, "ראה", TWOT, eds. 2:823; Francis Brown, et al., The New Brown, Driver, Briggs, Gesenius Hebrew and English Lexicon: With an Appendix Containing the Biblical Aramaic, trans. Edward Robinson (Peabody, MA: Hendrickson, 1979), 906-09; William L. Holladay, A Concise Hebrew and Aramaic Lexicon of the Old Testament (10 ${ }^{\text {th }}$ ed.; Grand Rapids, MI: Eerdmans, 1988), 327-28. 
provide," "to understand."17 These broadened meanings signify that the verb ראה signifies more than merely "seeing" or "looking" with the eyes. ${ }^{18}$ The verb communicates the complete and full experience of seeing in which the physical, mental, and intellectual apperceptions fuse. ${ }^{19}$ Clearly, the verb ראה comprises an elaborate and extensive range of meanings.

Considering the multilevel layers of meaning of the verb ראה, it should not be surprising that the verb has a rich theological context in the OT. The theological use of ראה in the OT indicates the panoramic scope of events in which individuals personally and intimately encounter God. In this divine/human encounter, God emerges from esotericism and discloses himself to humanity. "Thus [ראה] denotes the act of revelation itself, God's self-manifestation in person and in action." 20 To see God's face is to have a distinctive experiential encounter with God, an encounter that conveys the direct and instant relationship with God and the individual. Without a doubt, the act of ראה establishes a personal bond, an intimate solidarity between the one who is revealed and the one who sees (Exod 16:6-7; Job 19:27, 33:36, 42:5; Isa. 17:7, 33:17; Ezek 1:1.3). ${ }^{21}$

This close relationship that ראה creates between God and the individual who sees naturally yields a deep and authentic knowledge of God. In the book of Ezekiel, the divine recognition formula ("And they/you will know that I am Yahweh") occurs 72 times in the text. It appears 54 times in the third person and 18 times in the second person. However, apart from these 72 occurrences, the verb ראה appears twice in the divine recognition formula: 21:4[20:48] $]^{22}$ and 39:21. ${ }^{23}$ The occurrence of the verb ראה in the divine formula conveys a consummate understanding, a close, loving, experiential, and relational knowledge of YHWH's character. Thus, the hearers of Ezekiel's message do not merely possess cognitive knowledge of YHWH nor do they have objective, dispassionate, and detached opinions of YHWH. Rather, they enjoy an intimate

17 Culver, TWOT 2:823; Brown, Brown, Driver, Briggs; Holladay, A Concise Hebrew and Aramaic Lexicon of the Old Testament ; Edna and Yishai Tobin Aphek, Word Systems in Modern Hebrew: Implications and Applications (Leiden/New York/København/Köln: E.J. Brill, 1988), 17.

18 Amelia Rebecca Basdeo-Hill, "The Relationship between the Glory of Yahweh and the Holiness of Yahweh: A Literary-Theological Study from a Pentecostal Context," $\mathrm{PhD}$ thesis., University of South Africa, 2018), 74.

19 Fuhs, TDOT 9:214-15.

20 Fuhs, TDOT 9:229.

21 Fuhs, TDOT 9:229.

22 [20.48] is the English text.

23 Block, The Book of Ezekiel 1-24, 39. Per Walther Zimmerli, Ezekiel 1: A Commentary on the Book of the Prophet Ezekiel, Chapters 1-24 (trans. Ronald E. Clements; Philadelphia: Fortress, 1979), 38, the expression occurs 78 times with slight variations. 
understanding of who YHWH is, an understanding that is formed through a close encounter with YHWH's actions in the narrative. ${ }^{24}$

While in certain OT texts the verb ראה ("to see") produces a personal and sustained knowledge of YHWH, the verb [שמע] ("to hear") also effects a deeply affective knowledge of YHWH. Although the verb [שמע] is primarily translated as "hear," the word's usage in the OT reflects the more nuanced meanings than the simple idea of perceiving information or sound. ${ }^{25}$ All forms of the verb word [שמע] ("to hear") are found approximately 1160 times in 1072 verses, ${ }^{26}$ and is the most prevalent Hebrew term used for "obey" in the OT. ${ }^{27}$ The use of [שמע] ("to hear") for "obey" signifies that to effectively hear YHWH requires a response, indeed, an action that is congruent and consistent with what is heard. ${ }^{28}$

As previously stated, seeing and hearing are not merely sensory rational experiences of YHWH, but rather, seeing and hearing prescribe individuals to actively and affectively engage with YHWH. Progressive spiritual degeneration, apathy, and rebellion are predominant symptoms of failing to see and hear YHWH. To see and hear YHWH is to know YHWH. To know YHWH is to be in a close, dynamic relationship with him. A direct knowledge of YHWH requires a response of loving obedience to him. In Hebrew, knowledge of YHWH is synonymous with love for YHWH (cf. Ps 91:14). ${ }^{29}$

\section{THE THEME OF SEEING AND HEARING IN THE LITERARY UNIT OF EZEKIEL 37:1-14}

The themes of seeing and hearing create the literary structure of Ezekiel 37.1-14. Apart from Ezekiel's inaugural vision of YHWH's glory, Ezekiel 37:1-14 is possibly one of the most widely known texts of Ezekiel. ${ }^{30} \mathrm{With}$ carefully selected visual and auditory language, Ezekiel skilfully portrays to his hearers the grim scene of the valley of the dry bones, and by seamlessly blending the themes of

24 Cf. Jackie David Johns and Cheryl Bridges Johns, 'Yielding to the Spirit: A Pentecostal Approach to Group Bible Study', in Pentecostal Hermeneutics: A Reader (ed. Lee Roy Martin;Leiden/Boston: Brill, 2013), 33-56. This article was first published as Jackie David Johns and Cheryl Bridges Johns, 'Yielding to the Spirit: A Pentecostal Approach to Group Bible Study', Journal of Pentecostal Theology 1 (1992), 109-34.

25 Hermann J. Austel, '[mv', TWOT 2:938.

26 Even-Shoshan, New Concordance of the Old Testament, 1175-81.

27 Cf. Brown, Brown, Driver, Briggs, 1034.

28 R.W.L. Moberly, The Bible, Theology, and Faith (Cambridge: Cambridge University Press, 2000), 108.

29 Gregory Mobley, "Know, Knowledge," Eerdmans Dictionary of the Bible, 777.

30 Cf. Block, The Book of Ezekiel: Chapters 25-48, 370; Bruce Vawter and Leslie J. Hopp, Ezekiel: A New Heart (Grand Rapids: Eerdsman Publishing Company, 1991), 165; and Brian Neil Peterson, Ezekiel in Context: Ezekiel's Message Understood in its Historical Setting of Covenant Curses and Ancient near Eastern Mythological Motifs (Eugene, OR: Pickwick Publications, 2012), 229. 
seeing and hearing, the prophet assiduously constructs a literary framework for his message. ${ }^{31}$

Following the introductory formula in verse 1a, the first two verses focus on what Ezekiel sees as he is deposited in the valley, while verses 3-6 report the word that Ezekiel hears from YHWH. In verse 7, the dry bones hear the word of YHWH and Ezekiel hears the bones coming together. Then, in verse 8, Ezekiel sees flesh and skin cover the skeletons. After Ezekiel hears the word of YHWH in verse 9, in verse 10, the רוח hears Ezekiel's prophetic message, and Ezekiel sees the dry bones come alive. The pericope concludes with Ezekiel hearing the word of YHWH (vv. 11-14). Thus, the literary unit of Ezekiel 37:114 may be organized as follows:

i. Introductory formula (v. 1a)

ii. Ezekiel sees the valley of dry bones (vv. 1b-2)

iii. Ezekiel hears the word of YHWH (vv. 3-6)

iv. Hearing leads to seeing (vv. 7-8)

v. Ezekiel hears the word of YHWH (v. 9)

vi. Hearing leads to seeing (v. 10)

vii. Ezekiel hears the word of YHWH (vv. 11-14)

This structure clearly demonstrates the role and prominence of seeing and hearing in Ezekiel 37.1-14. Given the copious visual and auditory imagery in Ezekiel 37:1-14, it is no wonder that the themes of seeing and hearing create the shape of this literary unit.

\section{SEEING AND HEARING YHWH'S WORD IN THE DEATH VALLEY OF EZEKIEL 37.1-14}

Ezekiel 37:1-14 opens with the "hand of YHWH" seizing the prophet and transporting him to a nameless valley ${ }^{32}$ by the "spirit of YHWH" (v. 1). Hearers will recall that when Ezekiel first saw the majestic and awe-inspiring glory of YHWH, he was in a valley and the "hand of YHWH" was upon him (1:3). The last time the "hand of YHWH" gripped Ezekiel and carried him away by

31 For the various literary structure of Ezek. 37:1-14, see Block, The Book of Ezekiel: Chapters 25-48; Leslie C. Allen, Ezekiel 20-48 (Dallas, TX: Word Books, 1990); and Zimmerli, Ezekiel 2.

32 Zimmerli, Ezekiel 2, 258-59, provides a general review of the likely location of the valley. Block, The Book of Ezekiel: Chapters 25-48, 373, FN 51, notes that the prefixed article signifies that the valley has a precise location and Ezekiel's first hearers are familiar with the valley. 
YHWH's spirit, he saw the loathsome worship of idols in the temple and YHWH's glory leaving the temple and Jerusalem (chapters 8-11). What might Ezekiel experience during this outing by the spirit? Will Ezekiel see the glory of YHWH return to Jerusalem and the temple? Will YHWH's message in Ezekiel 36:1-38 be fulfilled? Will Ezekiel see and proclaim the end of the exile? Will the curse of the exile be reversed? Will the land of Israel be restored? Will the exilic community be able to return to their homeland? Given YHWH's message of salvation, hope, and restoration in Ezekiel 36:1-38, his hearers might anticipate a lush green valley with vast fields of blooming trees and flowers, towering emerald mountain peaks, rich oases, and a perfectly sculptured landscape. Instead, hearers see a frightening, grim, and lifeless valley. This valley, Ezekiel announces, is "full of bones" (v. 1).

Contemporary hearers who are already familiar with the narrative of Ezekiel 37:1-14 may have lost the ability to experience this event like Ezekiel is experiencing this vision. Ezekiel is seeing a scene of death, but hearers who are acquainted with the narrative may simply see the vision as another story because we have become desensitized to the horror of this vision. My aim, therefore, is to remind contemporary hearers how to see, hear, and experience Ezekiel's vision of the valley of bones anew.

To make certain that Ezekiel and his hearers grasp the full force of the scene, YHWH takes Ezekiel around and throughout the heaps of bones (v. 2). As Ezekiel walks across this "Death Valley," 33 his initial declaration, "and it was full of bones" in verse one, is heightened by the supplementary description in verse 2: "And behold, there were a great many bones upon the surface of the valley, and behold, they were very dry." Twice in verse 2, Ezekiel uses the word והנה ("and behold") to express his augmented horror at the ghastly sight of the massive piles of bones in the valley. According to Dennis J. McCarthy, in dreams and vision reports, the word ("and behold") underscores a profound and amplified emotional experience to an impressive and daunting sight. ${ }^{34}$ Thus, by using the word והנה ("and behold"), Ezekiel does not simply relate a factual statement about the bones, but also draws attention to his overwhelming emotional and exclamatory response to the sight of the dry bones. ${ }^{35}$ By pointing to his affective condition, Ezekiel compels his hearers to linger at the scene, to see and pay careful attention to the valley that is "full of bones." Accordingly, hearers notice three things: (1) the immense number of bones; (2) the bones are unburied and scattered across the valley; and (3) the extreme dryness of the bones.

33 Duguid, Ezekiel, 426, also uses this description.

34 Dennis J. McCarthy, "The Uses of Wehinnēh in Biblical Hebrew," Biblica 61 (1980/3): 332.

35 McCarthy, "The Uses of Wehinnēh in Biblical Hebrew," 331. 


\section{Basdeo-Hill, "Sights and Sounds," OTE 31/3 (2018): 534-552}

The scene Ezekiel paints is a harrowing picture of death. The image, however, is not an artistic representation of death, but is rather a blunt depiction of the brutality, savagery, and horror ${ }^{36}$ of the grisly scene Ezekiel had encountered. Ezekiel captures the ultimate "finality," 37 the irreversible end by describing the bones as "very dry" (v. 2). Clearly, death had viciously and ruthlessly erased the identity, ${ }^{38}$ strength, robustness, vigour, and life of those who had been slain. All that remained were extremely dry bones that signalled utter despair and hopelessness.

Ezekiel's portrait eliminates any notion that these bones could ever live again. Imagining life for these bones is to vehemently deny the truth. In fact, it would be outrageously absurd. Yet, as Ezekiel considers the despairing scene, Ezekiel hears, "Son of man, can these bones live" (v. 3)? What a preposterous question! Ezekiel has just seen a desolate wasteland filled with disjoined bones, all trace of life has long been removed, and YHWH asks, "... can these bones live?" For Ezekiel and his hearers who are also inspecting the scene, the answer is a resounding "No!" Clearly, YHWH's question serves to "heighten wonder" 39 and to seize the attention of Ezekiel and his hearers. It is also noteworthy that when Ezekiel first hears the voice of God, he does not hear his name being called, and he does not hear himself addressed as a priest or a prophet, but as "Son of man" (v. 3). As hearers meditate and marvel at YHWH's question, they hear Ezekiel say, 'O Lord YHWH, you know' (v. 3). Although Ezekiel's answer may

36 Block, The Book of Ezekiel: Chapters 25-48, 374.

37 Block, The Book of Ezekiel: Chapters 25-48, 374.

38 Certain scholars such as F.C. Fensham, "The Curse of the Dry Bones in Ezekiel 37:1-14 Changed to a Blessing of Resurrection," Journal of Northwest Semitic Languages 13 (1987): 59-60; Moshe Greenberg, Ezekiel 21-37: A New Translation and Commentary (New York: Doubleday, 1997), 748; and Peterson, Ezekiel in Context, 271 , contend that the bones in the valley belong to the slain Israelite army. Others propose that Ezekiel's vision in chapter 37:1-14 was influenced by ANE traditions. See, for example, B. Lang, "Street Theater, Raising the Dead, and the Zorastrian Connection in Ezekiel's Prophecy," in Ezekiel and His Book: Textual and Literary Criticism and Their Interrelation (ed. J. Lust; Leuven: Leuven University Press, 1986), 307-14. See also Greenberg, Ezekiel 21-37, 748; and Steven Tuell, Ezekiel (Peabody, MA: Hendrickson Publishers, 2009), 251, who disagree with Lang, "Street Theater, Raising the Dead, and the Zorastrian Connection in Ezekiel's Prophecy," 307-14, but also note that ANE culture may have helped shaped Ezekiel's imagery of the valley of dry bones. However, this author believes that any endeavour to identify the skeletal remains or the battle that might have left the remains seen in Ezekiel's vision result in misguided and injudicious scholarship.

39 Michael V. Fox, "The Rhetoric of Ezekiel's Vision of the Valley of the Bones," HUCA 51 (1980): 11. 
seem sombre and restrained, ${ }^{40}$ his response does not negate the creative power of YHWH, but rather reflects a moderate assurance in the power of YHWH to raise these dead and dry bones to life. ${ }^{41}$ It is as if Ezekiel is saying, "With people, this is impossible, but with you, YHWH, all things are possible. You know that only you have the power to raise these bones from the dead" (cf. Matt 19:26; Rom 8:11). While Ezekiel's response may be timid and guarded, hearers must recall that Ezekiel has seen and encountered the free, holy, powerful, and glorious splendour of YHWH in the valley (cf. chapter 1). Thus, it is possible that the prophet might now be encouraged to see beyond his present reality, and perhaps, even dare to have "hopeful imagination." 42

Somewhat unexpectedly, hearers hear YHWH give an enigmatic command: 'Prophesy over these bones and say to them: "'Dry bones, hear the word of YHWH'" (v. 4). Like his question in verse 3, YHWH's command in verse 4 seems baffling, illogical, and explicably peculiar. The dead are incapable of hearing! Surprisingly, despite the absurdity of YHWH's command, Ezekiel, without hesitation, prophesies to the dry bones (v. 7). As he is prophesying, Ezekiel first hears, and what he hears leads him to what he sees: "And behold, a quaking, and the bones came together, each bone to its bone. And I saw, and behold, sinews and flesh appeared on them, and skin spread over them from above, but there was no breath in them" (vv. 7-8). To see disjoined and dead bones come together and be covered with muscles, flesh, and skin is so unexpected, rare, extreme, and extraordinary that Ezekiel naturally responds with unconcealed astonishment. Furthermore, by using the word והנה ("and behold"), hearers are made aware of his unrestricted excitement, and thus anticipate an incredible sight.

As Ezekiel and his hearers watch with adrenalized exhilaration the sight of once dried and scattered bones morphing into bodies before their eyes, Ezekiel suddenly notices that the bodies have no breath in them (v. 8), signalling their lifeless state. Ezekiel's unforeseen observation heightens the dramatic tension for hearers. Everything was moving to the point of a miraculous resurrection when it was abruptly frustrated by the image of lifeless bodies. This perplexing and unexpected end ${ }^{43}$ increases hearers' disappointment as they recall YHWH's

40 Zimmerli, Ezekiel 2, 260; J.N. Grey, "Acts of the Spirit: Ezekiel 37 in the Light of Contemporary Speech-Act Theory," Journal of Biblical and Pneumatological Research 1 (2009): 75.

41 Zimmerli, Ezekiel 2, 260; Stefan Ohnesorge, Jahwe Gestaltet Sein Volk Neu: Zur Sicht Der Zukunft Israels Nach Ez 11, 14-21; 20,1-44; 36,16-38; 37,1-14.15-28, FzB 64 (Würzburg: Echter, 1991), 326.

42 Cf. Walter Brueggemann, Hopeful Imagination: Prophetic Voices in Exile (Philadelphia: Fortress Press, 1986); Helen Schüngel-Straumann, Ruach Bewegt Die Welt: Gottes Schöpferische Lebenskraft Der Krisenzeit Des Exils (Stuttgarter Bibelstudien Stuttgart: Verlag Katholisches Bibelwerk, 1992), 151, 56.

43 James Robson, Word and Spirit in Ezekiel (New York: T \& T Clark, 2006), 225. 
word to the dry bones: "I will bring breath in you, and you will live. I will give sinews to you, cover you with flesh, and spread over you a skin; I will give you breath, and you will live. Then you will know that I am YHWH" (vv. 5-6). In these verses, YHWH outlines a clear and systematic plan for revivifying the dry bones. ${ }^{44}$ The promise to infuse breath into the dry bones forms an inclusio, framing the word of YHWH to the dead bones. That is, YHWH's word begins and ends with the promise of breath, the life force of all living things. ${ }^{45}$ At the moment of their first breath, the resuscitated bones "will know that I am YHWH" (v. 6). Without a doubt, the sight of breathless bodies appears to discredit the word of YHWH. Certainly, hearers experience the dramatic tension. Suspense is elevated, and intrigue is created as hearers anxiously wait to see what will happen next.

At this point in the narrative, hearers hear the word of YHWH to Ezekiel: "Prophesy to the רוח. Prophesy, son of man, and say to the רוח: 'Thus says the Lord YHWH: From the four רוחות, come, and breathe in these slain corpses so that they may live"” (v. 9). On hearing the word of YHWH, Ezekiel prophesies to the רוח, and immediately, "רוח came into them, and they lived and stood on their feet, an extremely powerful, great army" (v. 10). For hearers, it is exceedingly difficult not to recall the creation story in Genesis 2:7 and its surrounding context. ${ }^{46}$ However, the purpose of this dichotomous revitalization activity in Ezekiel 3:7-10 does not imply that YHWH's initial word in verses 56 was ineffective or inadequate, ${ }^{47}$ but rather demonstrates the close relationship between YHWH's word and the spirit. The spirit does not substitute or supersede YHWH's word, but rather YHWH's word and the spirit are inextricably joined together in the creation process. The spirit is the life-giving, animating, and dynamic force that completes "what the word has started." 48 Thus, the acts of the spirit is conterminous with the word of YHWH. As this text implies, without YHWH's word, the spirit does not act. Instead, she ${ }^{49}$ hovers tremulously, moves

\footnotetext{
44 Robson, Word and Spirit in Ezekiel, 225.

45 R.G. Bratcher, "Biblical Words Describing Man: Breath, Life, Spirit," Bible Translator 34 (1983/4): 203.

46 Scholars who note the similarities between the two-phased process of creation in Ezekiel 37.7-10 and Genesis 2 are: Wilf Hildebrandt, An Old Testament Theology of the Spirit of God (Peabody, MA: Hendrickson Publishers, 1995), 18; R. Koch, Der Geist Im Alten Testament (Frankfurt am Main: Peter Lang, 1991), 26; Vawter and Hopp, Ezekiel, 53; C.R. Seitz, "Ezekiel 37.1-14," Interpretation 46 (1992/1): 53; Zimmerli, Ezekiel 2, 261; Block, The Book of Ezekiel: Chapters 25-48, 379; Duguid, Ezekiel, 427; and Wright, Message of Ezekiel, 307.

47 As suggested by Thomas Renz, The Rhetorical Function of the Book of Ezekiel (Leiden: Brill, 1999), 207.

48 Robson, Word and Spirit in Ezekiel, 230.

49 רוח is a feminine noun, and so requires a feminine pronoun.
} 
mysteriously, and waits steadily to recreate and transform creation ${ }^{50}$ at the sound of YHWH's creative word.

Unlike the clear, audible sound associated with the bones coming together in verse 7, Ezekiel surprisingly does not describe a sound as the spirit infuses breath into the corpses. As Ezekiel proclaims YHWH's word, hearers simply see breath enter the slain corpses, bringing them to life and raising them to their feet, "an exceedingly great army" (v. 10). In keeping with her mysterious nature, the spirit moves without being seen and without uttering a word, but she makes visible the effects of her presence. ${ }^{51}$ The spirit moves at the sound of YHWH's word, but she fulfils YHWH's word in a way that is creative, new, revolutionary, and unprecedented. ${ }^{52}$ On hearing YHWH's word to the spirit in verse 9, Ezekiel and his hearers anticipate the bones coming to life, but the sight of these once dried bones being raised from their unburied grave to a powerful and great army is certainly new and "unpredictable." 53

Moreover, the sight of the spirit raising the corpses to their feet may remind hearers of the Spirit raising Ezekiel to his feet in Ezekiel 2:2 and 3:24. When Ezekiel had seen and experienced the glorious and holy splendour of YHWH in the valley, twice, he threw himself to the ground in worship, and twice, the entered him and raised him to his feet (cf. 2:2 and 3:24). Thus, the רוח raising the dead bones from the ground mirrors the raising Ezekiel from the ground. Consequently, it is not far-fetched to infer that like the dead bones, the רוח also recreates, transforms, and breathes new life, vitality, and strength into Ezekiel. It is only when the רוח enters Ezekiel and raises him to his feet in $2: 2$, is he able to hear the word of YHWH. Keeping in mind the theological significance of hearing, the implication is plain: the activity of the רוח is essential for Ezekiel to hear, and thus obey the word of YHWH. Since the spirit's act of raising the dead bones to their feet emulates the raising of Ezekiel to his feet, the theological implication also applies to the raised army in Ezekiel 37:10.

The next thing Ezekiel and his hearers hear is YHWH explaining the incredible sight they had just seen (vv. 11-14). The image of the dry bones is pregnant with meaning as YHWH identifies "these bones" as "all the house of Israel" (v. 11), conveying that even the prophet himself is included in this symbolic picture of death. From this perspective, it was necessary for the רוח to breathe new life, vigour, and potency into Ezekiel. Ezekiel would not have been able to fulfil the task of his prophetic ministry as "dry bones." To stress that the gruesome picture of death in the opening scene is indeed the entire house of Israel, YHWH links the dreadful imagery to the exiles' lament: "Our bones are

50 Allen, Ezekiel 20-48, 185, also notes the spirit waits to transform.

51 Cf. Grey, "Acts of the Spirit," 81; and Ralph Del Colle, "The Holy Spirit: Presence, Power, Person," Theological Studies 62 (2001): 326.

52 Cf. Grey, "Acts of the Spirit," 81.

53 Grey, "Acts of the Spirit," 81. 
dry, our hope has perished; we are cut off' (v. 11). The exiles' pathos, their utter despondency, despair, hopelessness, and fear are poignantly heard in their lament.

This distressing cry heard in verse 11, recalls Ezekiel 33:10. There they say, "Our rebellious acts and our sins are upon us, and we are rotting away. How can we live?" In light of Ezekiel 37, the cry in 33:10 is striking for a few reasons. First, the effects of the exile have compelled the people to recognize their rebellion against YHWH as the reason for their affliction and misery. Second, their lament paints a torturous death from a putrefied wound. They are not yet dead, but the process of decomposition has already begun. The exiles know that there is no hope for life. When the mournful cry in 33:10 is juxtaposed with the image of the valley that is "full of bones" in $37: 1$, the picture is even more shocking. Death has long consumed its prey, the smell of rotting flesh no longer pervades the air, and tormented cries are no longer heard. Dried and brittle bones are all that can be seen. Third, in both texts (33:10 and 37:11), YHWH expresses knowledge of the exiles' laments, revealing that YHWH has heard their sorrowful groaning.

YHWH's hearing the cries of the exiled community leads to YHWH responding to their cries, and thus setting forth a series of hearing and responding from Ezekiel and the exilic community. For YHWH's word to take effect, Ezekiel must first hear the word of YHWH and then declare the word of YHWH to the exiles, implying that the exilic community must also hear the word of YHWH. YHWH's response entails five sequential actions, producing a pentalogy for Ezekiel and his hearers: (1) YHWH will open the graves of the house of Israel; (2) YHWH will raise Israel from their graves (v. 12); (3) YHWH will return the deportees to the land of Israel; (4) YHWH will 'give' the house of Israel YHWH's Spirit so that they may live; and (5) YHWH will give Israel rest in their 'own land' (vv. 12-14). Notably, YHWH is the subject of the action, and thus YHWH will "act in decisive and restorative ways" (cf. 37: 14) ${ }^{54}$

YHWH's word concerning the entire house of Israel is significant for several reasons. First, YHWH's dynamic saving acts signify a reversal of the experiences of the exile. The consequences of the exile is a "veritable graveyard," 55 conveying a sense of finality. However, the exile is not the end, and therefore is not permanent. ${ }^{56}$ YHWH himself will raise the entire house of Israel from the dead and lead them back to their homeland. Only YHWH "has the power to make a new beginning at the point where everything seems to have

54 Walter Brueggemann, Theology of the Old Testament: Testimony, Dispute, Advocacy (Minneapolis: Fortress, 1997), 123.

55 Allen, Ezekiel 20-48, 186.

56 Iain M. Duguid, Ezekiel and the Leaders of Israel, VTS 56 (Leiden: Brill, 1994), 46. 
come to an end." 57 Second, YHWH's act of salvation will cause the entire house of Israel to "know that I am YHWH" (vv. 13 and 14). Significantly, the recognition formula occurs three times in Ezekiel 37:1-14. The first appearance is in verse 6 after YHWH promises to cover the dead bones with tissues, flesh, and skin, and to place breath in them. Here, YHWH declares that Israel will "know that I am YHWH" when YHWH opens their graves and raises them from their graves (v. 13). They will also know YHWH after YHWH has placed "my רוח" (v. 14) in them and gives them "rest" in their homeland (v. 14). All three occurrences come after the promise of life. What is even more significant is that twice, the phrase comes after YHWH promises to place "a spirit" (v. 6) and "my spirit" (v. 14) in them. Additionally, it must be noted that the last appearance of the recognition formula, "Then they will know that I am YHWH," is tied closely to YHWH's assertion: "I have spoken, and I will act" (v. 14). Indeed, only YHWH, has the power to give life to bones that have long been dead. Such a powerful display of YHWH's acts only evinces "YHWH's being." 58 Moreover, Israel will also know that YHWH not only speaks, but he acts. ${ }^{59}$

Third, YHWH refers to Israel as "my people" (vv. 12 and 13), expressing the covenant reality that the entire house of Israel will once again experience. Fourth, the interpretation of the term רוח easily moves back and forth between רוח as "breath" and "wind" to רוח as the spirit of YHWH, 60 indicating that "breath" and "wind" in Ezekiel 37:1-14 is simultaneously the spirit of YHWH. Ezekiel 37:1-14 certainly highlights the polyvalence nature of רוח, but the precise meaning of the term as "breath," "wind" or "spirit" is not so easily identified in the text. It is as though the text intentionally blurs the meanings of the term ${ }^{61}$ so as to intensify the mysterious nature of the רוח. Undoubtedly, "Yahweh's spirit is at once Israel's breath and at the same time a wind gathered from the four compass points." 62 Clearly, the spirit of YHWH is the life force of all living things. Without YHWH's רוח, life ceases to exist. ${ }^{63}$

\section{E IMPLICATIONS OF SEEING AND HEARING EZEKIEL 37.1-14}

In summarizing the foregoing discussion on seeing and hearing in Ezekiel 37.114 , it is clear that the acts of seeing and hearing summon hearers to see and hear Scripture afresh, to engage anew with overfamiliar and difficult texts, and to

\footnotetext{
57 Zimmerli, Ezekiel 2, 265.

58 Allen, Ezekiel 20-48, 185.

59 Duguid, Ezekiel, 428.

60 Robson, Word and Spirit in Ezekiel, 230, argues that there is a clear shift from between רוז as 'breath' and 'wind' to רוח as the spirit of YHWH. However, I agree with Seitz, "Ezekiel 37:.1-14," 53, that there is not a clear cut meaning of רוח in this text.

61 Grey, "Acts of the Spirit," 77.

62 Seitz, "Ezekiel 37.1-14," 53.

63 Cf. Pieter De Vries, "The Relationship between the Glory of Yahweh and the Spirit of Yahweh in Ezekiel 33-48," OTE 28 (2015/2): 337.
} 
encounter the living God in the written word of God. In the book of Ezekiel, the themes of seeing and hearing $\mathrm{YHWH}$ are directly connected to obedience to YHWH. Accordingly, to see YHWH is to hear YHWH, and to hear YHWH is to know and obey YHWH. Conversely, to hear YHWH is to see YHWH, and to see YHWH is to know and obey YHWH. A failure to see and hear YHWH is to wilfully and consciously revolt against YHWH. Thus, seeing and hearing function as a singular act of perception in the book of Ezekiel. No wonder the book of Ezekiel is filled with visual and auditory imagery that is dramatic, eccentric, and unconventional. Ezekiel must employ creative techniques to proclaim YHWH's message to a people who refuse to hear the word of YHWH (cf. 2:7). He paints such vivid and powerful images that compel his hearers to see and hear along with him.

The seeing and hearing of YHWH's word in Ezekiel 37:14, effected life and restoration to the dead bones. After Ezekiel saw the heaps of dead bones in the valley (v. 1), Ezekiel heard the word of YHWH and then obeyed the word of YHWH (vv. 3-6). Although the task of prophesying to dead bones might seem ridiculous, Ezekiel obeys YHWH (v. 7) because Ezekiel has already seen and heard the awesome and powerful glory of YHWH (cf. chapters 1-3 and 8-11). As Ezekiel prophesies, the dead bones hear the word of YHWH, and Ezekiel sees the bones come together and flesh and skin cover them (vv. 7-8). Then, Ezekiel hears the word of YHWH and prophesies to the (v. 9). The רוח also hears the word of YHWH, obeys the word of YHWH, and infuses breath into the corpses, bringing them to life (v. 10). The literary unit closes with Ezekiel hearing the word of YHWH to the house of Israel, implying that Israel must now hear and see the word of YHWH (vv. 11-14).

Additionally, the seeing and hearing of Ezekiel 37:1-14 reveal several striking characteristics of YHWH. First, it shows YHWH's faithful and steadfast love for Israel. Although the word "love" does not appear in Ezekiel 37:1-14, the theme of YHWH's love is implied in this literary unit. The first thing that confronts Ezekiel in the valley is an extraordinarily gruesome and graphic scene of piles and piles of dead bones. The scene depicts total death, symbolizing the current state of the entire house of Israel. It is necessary for Ezekiel and his hearers to see this horrific sight because it concretizes the consequences of rebellion against YHWH. The ghastly massacre and scattering of the bones might give the sense that YHWH has terminated his relationship with Israel. ${ }^{64}$ However, YHWH's devoted love for Israel will not allow YHWH to forsake Israel, and thus, YHWH will not completely destroy Israel. YHWH's promise to restore the whole house of Israel is certainly not earned or merited (cf. 36:31-

64 John Goldingay, Old Testament Theology: Israel's Faith (Downers Grove, IL: InterVarsity Press, 2006), 2:354. 
32). ${ }^{65}$ Still, YHWH's faithful love for Israel guarantees a reversal of the exile and a complete restoration and transformation of the people. Thus, the picture of death in the opening scene of Ezekiel 37 is replaced by an image of life, hope, and renewal.

Second, YHWH is creator. Thus, Israel's existence is contingent on YHWH's creative and life-giving power to sustain life. ${ }^{66}$ Raising dead bones back to life would certainly be viewed as impossible; "however it is exactly the peculiar capacity of YHWH to make it possible. It is this impossibility that sustains the life of Israel." 67 It is also this impossibility that asserts and evinces the incomparable power of YHWH to create and recreate life, exposing therefore, the impotence and fraudulence of all other gods. ${ }^{68}$

Third, YHWH is a God of hope. The lament heard in 37:11: "Our bones are dry, and our hope has perished; we are cut off," portrays the exiles' state of hopelessness. Thus, the accent of YHWH's promise of hope is in transformation and restoration. Even in the face of death Israel's hope in the future is grounded in the sovereignty of YHWH. ${ }^{69}$

Ezekiel 37:1-14 is an invitation for hearers to see and hear YHWH. Seeing and hearing $\mathrm{YHWH}$ allow hearers to fully encounter $\mathrm{YHWH}$, to experience YHWH's glory, and to know YHWH intimately.

\section{BIBLIOGRAPHY}

Allen, Leslie C. Ezekiel 20-48. Word Biblical Commentary. Dallas, TX: Word Books, 1990.

Aphek, Edna and Yishai Tobin. Word Systems in Modern Hebrew: Implications and Applications. Leiden/New York/København/Köln: E.J. Brill, 1988.

Austel, Hermann J. "[שמע," in Theological Wordbook of the Old Testament, edited by R. Laird Harris, Gleason Leonard Archer, and Bruce K. Waltke, 938-39. Chicago: Moody Press, 1980.

Basdeo-Hill, A.R. "The Relationship Between the Glory of Yahweh and the Holiness of Yahweh in the Book of Ezekiel: A Literary Theological Study From a Pentecostal Context." PhD. University of South Africa, 2018.

Block, Daniel I. The Book of Ezekiel: Chapters 1-24. New International Commentary on the Old Testament. Grand Rapids: Eerdmans, 1997.

. The Book of Ezekiel: Chapters 25-48. New International Commentary on the Old Testament. Grand Rapids: Eerdmans, 1998.

65 Paul M. Joyce, Divine Initiative and Human Response in Ezekiel, (Sheffield: JSOT Press, 1989), 51, 127.

66 Walter Brueggemann, Old Testament Theology: An Introduction (Library of Biblical Theology; Nashville: Abingdon Press, 2008), 160.

67 Brueggemann, Old Testament Theology, 158.

68 Brueggemann, Old Testament Theology, 150.

69 Brueggemann, Old Testament Theology, 484-85. 
Bratcher, R.G. "Biblical Words Describing Man: Breath, Life, Spirit." Bible Translator 34, 4 (1983): 201-09. https://doi.org/10.1177/026009438303400201

Brown, Francis, et al. The New Brown, Driver, Briggs, Gesenius Hebrew and English Lexicon: with an Appendix Containing the Biblical Aramaic. Translated by Edward Robinson. Peabody, MA: Hendrickson, 1979.

Brueggemann, Walter. Hopeful Imagination: Prophetic Voices in Exile. Philadelphia: Fortress Press, 1986.

Finally Comes the Poet: Daring Speech for Proclamation. Minneapolis: Fortress Press, 1989.

. Theology of the Old Testament: Testimony, Dispute, Advocacy. Minneapolis: Fortress, 1997.

Old Testament Theology: An Introduction. Library of Biblical Theology;

Nashville: Abingdon Press, 2008. https://doi.org/10.1093/oxfordhb/97801992 37777.003 .0038

Colle, Ralph Del. "The Holy Spirit: Presence, Power, Person." Theological Studies 62 (2001): 322-40. https://doi.org/10.1177/004056390106200205

Culver, Robert D. "ha'r"." In Theological Wordbook of the Old Testament, edited by Harris, R. Laird, Gleason Leonard Archer and Bruce K. Waltke. Vol. 2. Chicago: Moody Press, 1980.

De Vries, Pieter. "The Relationship Between the Glory of Yahweh and the Spirit of Yahweh in Ezekiel 33-48," Old Testament Essays 28, no. 2 (2015): 326-50. https://doi.org/10.17159/2312-3621/2015/V28N2A7

Duguid, Iain M. Ezekiel and the Leaders of Israel. Vetus Testamentum Supplements. Vol. 56. Leiden: Brill, 1994. https://doi.org/10.1163/9789004275805 Ezekiel. Grand Rapids: Zondervan, 1999.

Even-Shoshan, Abraham. A New Concordance of the Old Testament: Using the Hebrew and Aramaic Text. $2^{\text {nd }}$ ed. Jerusalem: "Kiryat-Sefer," 1989.

Fensham, F.C. "The Curse of the Dry Bones in Ezekiel 37.1-14 Changed to a Blessing of Resurrection." Journal of Northwest Semitic Languages 13 (1987): 59-60.

Fox, Michael V. "The Rhetoric of Ezekiel's Vision of the Valley of the Bones." Hebrew Union College Annual 51 (1980): 1-15.

Fuhs, Hans F. "ha'r"." In Theological Dictionary of the Old Testament, edited by Botterweck, Johannes G., Helmer Ringgren and Heinz-Josef Fabry, 208- 242. Vol. 9. Grand Rapids, MI: William B. Eerdmans Publishing Company, 2004.

Goldingay, John. Old Testament Theology: Israel's Faith. Vol. 2. Downers Grove, IL: InterVarsity Press, 2006.

Green, Garrett. "The Bible As ...':Fictional Narrative and Scriptural Truth." In Scriptural Authority and Narrative Interpretation, edited by Garrett Green, 7986. Philadelphia: Fortress Press, 1987.

Greenberg, Moshe. Ezekiel 21-37: A New Translation and Commentary. The Anchor Bible; New York: Doubleday, 1997.

Grey, J.N. "Acts of the Spirit: Ezekiel 37 in the Light of Contemporary Speech-Act Theory." Journal of Biblical and Pneumatological Research 1 (2009): 69-82.

Hildebrandt, Wilf. An Old Testament Theology of the Spirit of God. Peabody, MA: Hendrickson Publishers, 1995.

Holladay, William L. A Concise Hebrew and Aramaic Lexicon of the Old Testament. $10^{\text {th }}$ ed. Grand Rapids, MI: Eerdmans, 1988. 
Johns, Jackie David and Cheryl Bridges. "Yielding to the Spirit: A Pentecostal Approach to Group Bible Study." In Pentecostal Hermeneutics: A Reader, edited by Lee Roy Martin, 33-56. Leiden/Boston: Brill, 2013. https://doi.org/10.1163 19789004258259_005

Joyce, Paul M. Divine Initiative and Human Response in Ezekiel. Journal for the Study of the Old Testament Supplement. Sheffield: JSOT Press, 1989.

Klouda, Sheri L. "The Dialectical Interplay of Seeing and Hearing in Psalm 19 and Its Connection to Wisdom." Bulletin for Biblical Research 10.2 (2000): 181-95.

Koch, R. Der Geist Im Alten Testament. Frankfurt am Main: Peter Lang, 1991.

Lang, B. "Street Theater, Raising the Dead, and the Zorastrian Connection in Ezekiel's Prophecy." In Ezekiel and His Book: Textual and Literary Criticism and Their Interrelation, edited by J. Lust Leuven: Leuven University Press, 1986.

McCarthy, Dennis J. "The Uses of Wehinnēh in Biblical Hebrew." Biblica 61, no. 3 (1980): 330-42.

Moberly, R.W.L. The Bible, Theology, and Faith. Cambridge: Cambridge University Press, 2000. https://doi.org/10.1017/CBO9780511612404

Mobley, Gregory. "Know, Knowledge." In Eerdmans Dictionary of the Bible, edited by David Noel Freedman, Allen C. Meyers, and Astrid B. Beck. Grand Rapids, MI/Cambridge, UK: Wm. B. Eerdmans Publishing Co., 2000.

Ohnesorge, Stefan. Jahwe Gestaltet Sein Volk Neu: Zur Sicht Der Zukunft Israels Nach Ez 11, 14-21; 20,1-44; 36,16-38; 37,1-14.15-28. Forschung zur Bibel 64. Würzburg: Echter, 1991.

Peterson, Brian Neil. Ezekiel in Context: Ezekiel's Message Understood in Its Historical Setting of Covenant Curses and Ancient near Eastern Mythological Motifs. Princeton Theological Monograph Series. Eugene, OR: Pickwick Publications, 2012.

Renz, Thomas. The Rhetorical Function of the Book of Ezekiel. Leiden: Brill, 1999. https://doi.org/10.1163/9789004276017

Robson, James. Word and Spirit in Ezekiel. New York: T \& T Clark, 2006.

Schüngel-Straumann, Helen. Ruach Bewegt Die Welt: Gottes Schöpferische Lebenskraft Der Krisenzeit Des Exils. Stuttgarter Bibelstudien Stuttgart: Verlag Katholisches Bibelwerk, 1992.

Seitz, C.R. "Ezekiel 37.1-14." Interpretation 46, 1 (1992), 53-56.

Thomas, John Christopher. The Apocalypse: A Literary and Theological Commentary. Cleveland, TN: CPT Press, 2012.

Tuell, Steven. Ezekiel. Old Testament Series: New International Biblical Commentary Peabody, MA: Hendrickson Publishers, 2009.

Vawter, Bruce and Leslie J. Hopp. Ezekiel: A New Heart. International Theological Commentary. Grand Rapids: Eerdmans Publishing Company, 1991.

Van Wolde, Ellen. "The God Ezekiel 1 Envisions."In The God Ezekiel Creates, edited by Paul M. Joyce and Dalit Rom-Shiloni, 87-106. London: Bloomsbury T\&T Clark, 2015.

Wessels, Wilhelm J. "Prophetic Sensing of Yahweh's Word", HTS Teologiese Studies/ Theological Studies 71(3). 9 pages. http://dx.doi.org/10.4102/hts.v71i3.2923. https://doi.org/10.4102/hts.v71i3.2923

Wright, Christopher J. H. The Message of Ezekiel: A New Heart and a New Spirit. The Bible Speaks Today. Leicester: Inter-Varsity, 2001. 
552 Basdeo-Hill, "Sights and Sounds," OTE 31/3 (2018): 534-552

Zimmerli, Walther. Ezekiel 1: A Commentary on the Book of the Prophet Ezekiel, Chapters 1-24. Translated by Ronald E. Clements. Hermeneia. Philadelphia: Fortress, 1979.

Ezekiel: A Commentary on the Book of the Prophet Ezekiel Chapters 2548. Translated by James D. Martin. Hermeneia. Philadelphia: Fortress Press, 1983.

Dr. Amelia Rebecca Basdeo-Hill, Coordinator of Degree Programs and Student Academics, Pentecostal Theological Seminary, Email: bhill@ptseminary.edu.

ORCID ID: https://orcid.org/0000-0002-5865-8230 